\title{
Travel to school and urban structure in medium and small sized cities: a case study of Castelo Branco
}

\author{
R. M. Alves, S. A. Duarte \& M. I. Calcinha \\ Escola Superior de Tecnologia de Castelo Branco, Portugal
}

\begin{abstract}
Journeys from home to school represent a significant portion of all urban commuting. A high number of citizens are involved. Not only students but parents, relatives, friends and individuals make up this group. These journeys have a relevant impact on urban environments because they correspond to the time (Peak Hour) and the spatial needs of other kinds of journeys that apply to other types of families and activities. The aim of this paper is to relate the urban zone with modal split of four schools in a medium sized Portuguese city, in aggregate form by school and by grades. These schools include children and adolescents from the $1^{\text {st }}$ grade until $9^{\text {th }}$ grade in a group age of 6-10 $\left(1^{\text {st }}-4^{\text {th }}\right.$ grade) $10-11\left(5^{\text {th }}-6^{\text {th }}\right.$ grade $)$ and $12-14$ years old $\left(7^{\text {th }}-9^{\text {th }}\right.$ grade $)$. The differences between mobility patterns in journeys to/from school by school and by grade are evident. Walking is the main travel to school mode choice in three schools and driving in one school. Driving is the main travel to school mode choice for the students from the $1^{\text {st }}$ to $6^{\text {th }}$ grades and walking for the students from $7^{\text {th }}$ to $9^{\text {th }}$ grades. According to the results, the urban zone influences the mobility patterns in journeys to/from school, however for small and medium sized city that influence does not appear to be so evident.
\end{abstract}

Keywords: built environment, scholar mobility patterns, medium and small sized cities, children, students and adolescents.

\section{Introduction}

Several countries place particular importance on promoting sustainable urban mobility policies and physical activity on to/from school journeys. Through programs, information and awareness campaigns, targeted at students and 
families, the objective is to instill sustainable, healthy and active transport mode choices [1-7]. Several National Transports Strategies have been promoted towards sustainable mobility with a focus in scholar mobility to change the present mobility patterns $[3,5]$. European Union approved the Green Paper: Towards a new Culture for Urban Mobility attaching the Action Plan on Urban Mobility towards scholar mobility [8].

A great number of studies about mobility patterns and particularly scholar mobility report for metropolitan areas. However, medium and small sized cities present more sustainable patterns of mobility and scholar mobility than larger urban and metropolitan areas. The proximity of residence, other public services, school, community services, commerce and services, correspond to a lower distance of the journeys and higher facility to plan the journeys by different reasons and, consequently, less times a day. The low number of traffic motorized flow and higher intensity of social relations, of inter-knowledge, of community and vicinity and higher safety feel, stimulate the choice of active transport modes, specially walk and bicycle [9].

This paper intends to relate, in a general way, the mobility patterns of the students, from four schools, with the urban zone of a small Portuguese city.

\section{Built environment and scholar mobility}

Travel to school modal choices are influenced by different interactive factors that are tied to urban form, individual, social and economic aspects. These findings are analyzed particularly with respect to health and physical activity promotion, in the context of planning and transportation [10-15].

The researchers give special attention to urban structure (or urban form or built environment) characteristics and what influence they have on parents transport mode choices and how their children make and behave during their journeys to/from school.

Urban Structure include not only "the design of the city and the physical elements within it, including both their arrangement and their appearance, and is concerned with the function and appeal of public spaces" (Handy et al. [11]), or "density, mixed uses, connectivity, proximity and design" (Cervero and Kockelman [16]) but also functional aspects connected to traffic flow, and public transports system, etc.

According to Panter et al. [14] the indicators of urban structure frequently incorporated in the models correlate to the availability and transport infrastructure characteristics, safety road, urban blocks form, density and diversity of land use and the distance home to school. These indicators were obtained to the vicinity of student residences and to the vicinity of the school [9]. Further, GIS is an important tool to characterize urban zone and to analyze the spatial relations. 


\section{Local and scope of the study}

This paper presents a case study of an ongoing research project being developed in a medium sized city of Portugal about journeys to/from school. The aim of the project is to promote sustainable mobility to/from school journeys in a partnership with the Municipality, the local transport operator and the support of Fundação Calouste Gulbenkian [17].

Castelo Branco has 30000 inhabitants, 45 schools from kindergarten until university and 12000 students. It's estimated that daily journeys to school directly involve 16000 of people within the city. This paper presents the results from four schools (Afonso de Paiva (EBAP), Cidade de Castelo Branco (EBCCB), Faria de Vasconcelos (EBFV) e João Roiz (EBJR)). These schools have similar number of students (children and adolescents), grades $\left(1^{\text {st }}-9^{\text {th }}\right)$ and students aged (6-14 years old). All schools have the total of 2134, 363 from the $1^{\text {st }}$ to $4^{\text {th }}$ grade $(6-10$ years old; $17,0 \%), 824$ from the $5^{\text {th }}$ and $6^{\text {th }}$ grade $(10-11$ years old; $38,6 \%$ ) and 947 from the $7^{\text {th }}$ to $9^{\text {th }}$ grade (12-14 years old; 44, 4\%).

The characteristics of the urban zones where the schools are located are different. Two of them are near the city center (EBJR and EBAP) and the other two in the periphery of the city (table 1 and fig.1).

Table 1: $\quad$ Characteristics of urban zones where schools are located.

\begin{tabular}{|c|c|c|c|c|}
\hline $\begin{array}{c}\text { Urban Network } \\
\text { Street }\end{array}$ & EBAP & EBCCB & EBFV & EBJR \\
\hline Schools Location & $\begin{array}{c}\text { Central } \\
\text { Urban Area }\end{array}$ & $\begin{array}{c}\text { Urban } \\
\text { Periphery }\end{array}$ & $\begin{array}{c}\text { Urban } \\
\text { Periphery }\end{array}$ & $\begin{array}{c}\text { Near to City } \\
\text { Center }\end{array}$ \\
\hline Typology & $\begin{array}{c}\text { Mixed Uses } \\
\text { High } \\
\text { Density }\end{array}$ & $\begin{array}{c}\text { Particularly } \\
\text { Residential } \\
\text { Low Density }\end{array}$ & $\begin{array}{c}\text { Residential } \\
\text { High Density }\end{array}$ & $\begin{array}{c}\text { Mixed Uses } \\
\text { High } \\
\text { Density }\end{array}$ \\
\hline Community Area & High & Low & Low & High \\
\hline Employment Places & 2500 & 150 & 800 & 1500 \\
\hline $\begin{array}{c}\text { Bus Stop (<200 m) } \\
\text { Frequencies (8 a.m. } \\
-6 \text { p.m.) }\end{array}$ & 32 & 50 & 7 & 58 \\
\hline
\end{tabular}

The urban zone of EBCCB stands out among the other three schools, considering that is located in an urban area of spontaneous growth, of low density, particularly residential, with single-family houses, and limited public spaces. The urban zone of EBFV is characterized particularly by a residential area of high density but with a lack of public and community space. The urban zone that characterizes EBAP and EBJR are central at the city resulted from the city growth. The vicinity of both schools is characterized by high density and 
diversity of land uses particularly commerce and services areas. The mainly part of the influence zone of both schools is shared because they are only in a distance of 300 meters.

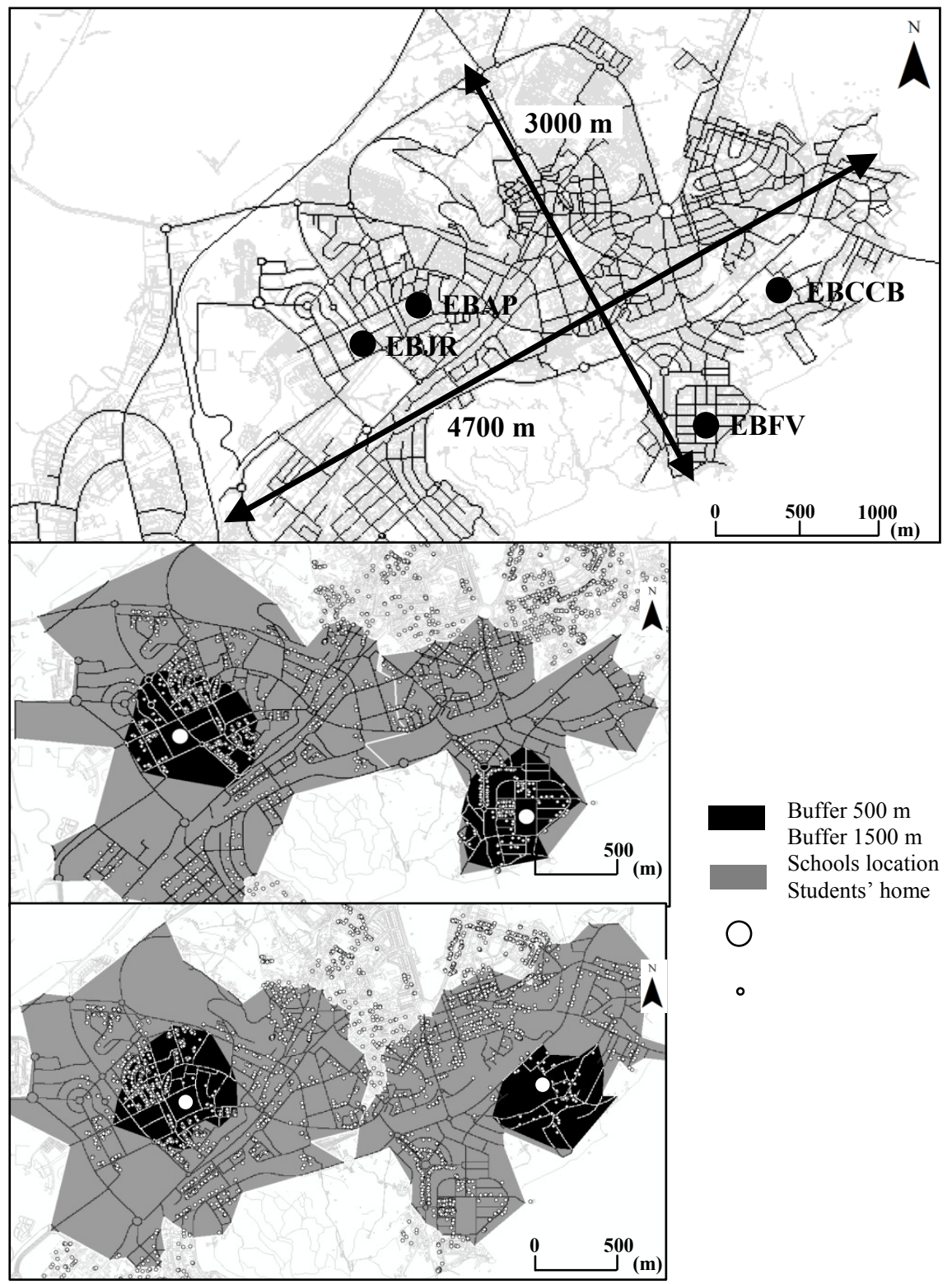

Figure 1: Schools location in urban area of Castelo Branco and school influences zones (500 and 1500 meters). 


\section{Methodology}

Streets, schools, 1613 students ( $81 \%$ of the total) and urban structure of each school were introduced in GIS. At the same time, data was collected from students and parent's surveys about mobility practices in their journeys to/from school: 1647 answers from students and 778 from parents were validated.

From the streets networks and the location of the schools two buffers of 500 and 1500 meters to each school per street were defined. The 500 meter buffer defines the area of the school where it is expectable that, considering the proximity of the residences to the school and feelings of security, that most of the journeys be undertaken by walking or by bicycling. Within 500 meter buffer it would be expected that the journey take less than 5 minutes for both transport modes. The 1500 buffer represents the maximal distance that Portuguese rules recommend to these school grades. Within and out of each buffer for each school the information regarding the students by school and grade, urban structure and students distance from their home to school was obtained.

By the surveys information was obtained, by school and by school grade, the choices of transport modes the time of the students and parents' journeys to/from school and the additional time of journeys that parents expend to take and pick up children to school during their way to work.

Through spatial analyses and surveys several indicators were obtained (table 2). Finally, the estimated daily $\mathrm{Co}_{2}$ emissions by school and school grade were calculated.

\section{Results}

The actual stage of the Project only provides to analysis of aggregated results by grade groups and school.

\subsection{Spatial students distribution}

1286 of the students have their home (63\% of the total), in the buffer area of 500 meters (table 3). However, only 525 of the students (41\%) attend the schools in study, the others attend to other schools. The higher attractiveness rate is located in urban periphery schools (EBFV: $62 \%$ and EBCCB: $68 \%$ ). In the buffer area of 1500 meters from each school are located 1613 students ( $80 \%$ of the total) from which $86 \%$ attends to the four schools in study. The higher attractiveness rate is EBCCB and EBJR with $20 \%$ for both (see table 2).

The average of the home to school distances by student is 306 meters within 500 meters buffer and 755 meters within 1500 meters buffer and 1464 for all the coverage area of the city. The average distance by student from each school, considering the entire city, present significant differences, is 1046 meters in EBJR and 2298 meters in EBFV. 


\subsection{Urban structure}

The indicators used to characterize the urban structure, considering the dimension/volume, density/intensity or diversity, shows differences between schools from the city center and schools from the periphery, particularly within 500 meters buffer. Within the buffer of 1500 meters, the differences are not so significant because of the small size of the city. The 1500 meters buffers overlap and the differences gradually fade (see table 2).

\subsection{Modal split}

Journeys to and from school are mainly made walking (49\%), driving (45\%) and by public transport mode $(5 \%)$.

Nevertheless the results, allows ones identify differences between the modal split to school and back home. In the return journeys, walking mode transport choice increase. Driving to school is major in three schools representing $51 \%$ of the trips meanwhile the return journeys are only $37 \%$. Walking appears has the higher number of journeys from school increasing $43 \%$ to $58 \%$ (table 3 ).

Mobility Patterns are different from the $1^{\text {st }}$ until $9^{\text {th }}$ grades. For the $1^{\text {st }}$ until $6^{\text {th }}$ driving represent the high number of trips $(55 \%$ and $49 \%)$, meanwhile in the $7^{\text {th }}$ until $9^{\text {th }}$ grade walking appears to be the main travel mode choice $(58 \%)$.

\subsection{Journeys time}

Students' journeys time to/from school is similar for all studied grades in the schools. The average journeys time is 7,2 minutes for students and 7,1 for parents according to the data surveys. For the 5 minutes are included $37 \%$ of the total of the journeys for all grades to/from school. $94 \%$ of the journeys to/from school present duration under 15 minutes.

Additional journey times of parents to take their children to school driving on their way to work, or at the end of the day to bring them back, represent an average duration of 8,2 minutes, with different values when comparing with the morning period (3,6 minutes) against the return (8,9 minutes). For the additional daily time of 5 minutes to take the children to school and bring them back are included in $37 \%$ of journeys in the total of the study schools. For this additional 5 minutes a day, spent by parents, considerable differences between morning journeys to school $(46 \%)$ and return journeys (31\%) is observed. Under the 15 minutes are included $88 \%$ of the journeys (79\% to school and $66 \%$ from school).

\subsection{Adults accompanying children to school}

Journeys to/from school are mainly made by parents, adults and family independently of their transport modes choices. For the $1^{\text {st }}$ until $4^{\text {th }}$ grade, children's journeys to/from school in the company of family represent the highest number. In the total of the four schools of study the $1^{\text {st }}$ until $9^{\text {th }}$ grade $36 \%$ of the journeys are made in adults' company ( $44 \%$ for the $1^{\text {st }}$ until $6^{\text {th }}$ grade 


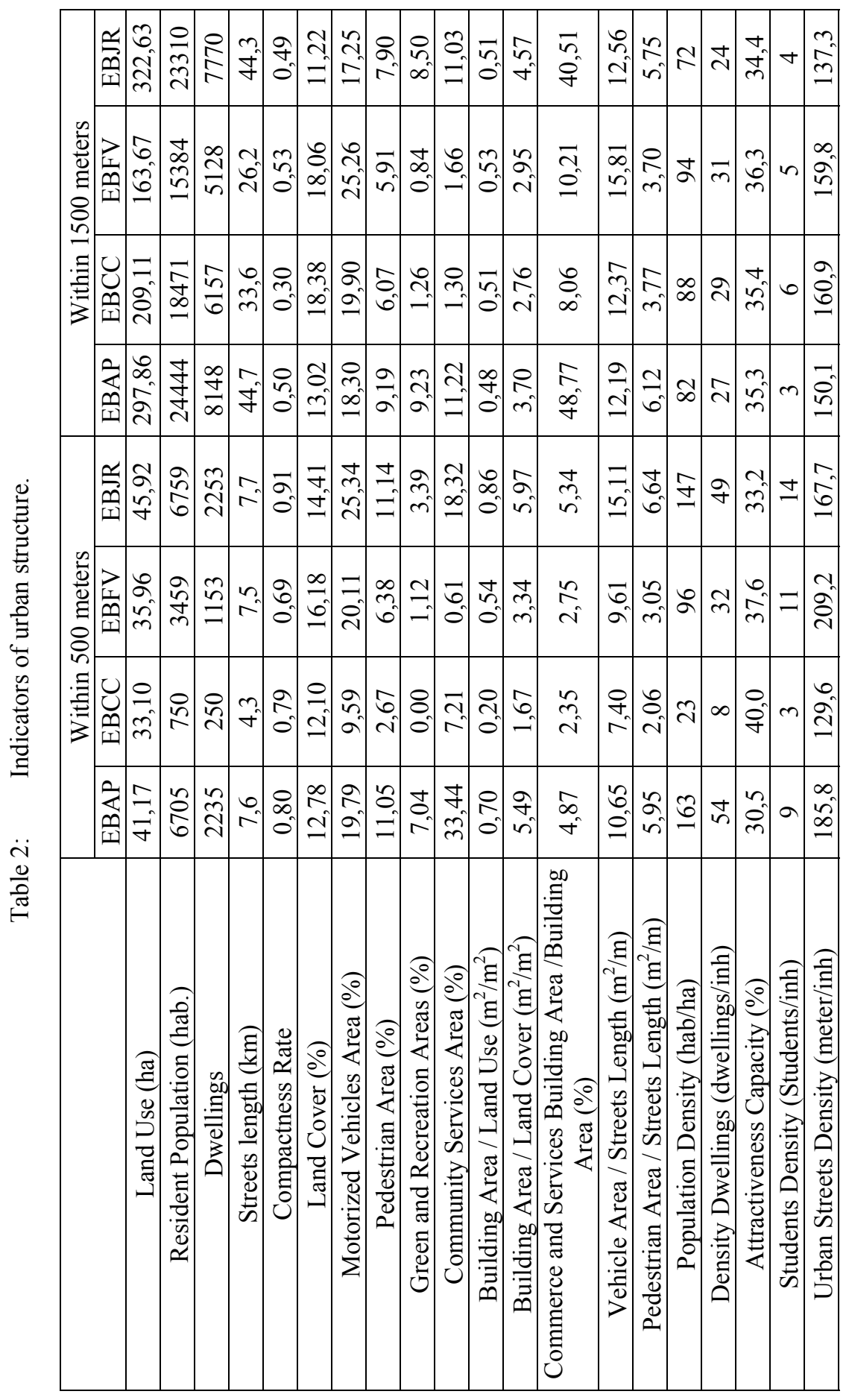


Table 3: Indicators of mobility patterns.

\begin{tabular}{|c|c|c|c|c|c|}
\hline & EBAP & EBCCB & EBFV & EBJR & TOTAL \\
\hline Walking to school (\%) & 48 & 35 & 62 & 54 & 49 \\
\hline Driving to school (\%) & 47 & 59 & 33 & 39 & 45 \\
\hline $\begin{array}{c}\text { Distance per student in 500 } \\
\text { buffer }\end{array}$ & 337 & 229 & 263 & 359 & 316 \\
\hline $\begin{array}{c}\text { Distance per student in 1500 } \\
\text { buffer }\end{array}$ & 728 & 985 & 630 & 628 & 755 \\
\hline Distance per student (meters) & 1186 & 1477 & 2298 & 1046 & 1464 \\
\hline Journey time/ student (minutes) & 7,9 & 9,8 & 6,4 & 8,6 & 7,2 \\
\hline $\begin{array}{c}\text { Additional Journeys times of } \\
\text { parents /student (min.) }\end{array}$ & 1,8 & 4,1 & 2,9 & 4,8 & 8,2 \\
\hline $\begin{array}{c}\text { Additional distance of parents / } \\
\text { student (min.) }\end{array}$ & 890 & 2061 & 1458 & 2423 & 4100 \\
\hline $\begin{array}{c}\text { Co } 2 \text { Emissions/student/day } \\
\text { (gr/student/day) }\end{array}$ & 219 & 451 & 349 & 410 & 368 \\
\hline $\begin{array}{c}\text { Additional Co } 2 \text { Emissions of } \\
\text { parents/student/day } \\
\text { (gr/student/day) }\end{array}$ & 125 & 289 & 204 & 339 & 248 \\
\hline $\begin{array}{c}\text { Co } 2 \text { Emissions of student's } \\
\text { journeys/student/day } \\
\text { (gr/student/day) }\end{array}$ & 94 & 163 & 145 & 70 & 119 \\
\hline Journeys in adults company (\%) & 26 & 45 & 33 & 31 & 35 \\
\hline $\begin{array}{c}\text { Journeys in adults company by } \\
\text { walking (\%) }\end{array}$ & 15 & 11 & 28 & 14 & 16 \\
\hline $\begin{array}{c}\text { Number of Students } \\
\text { Numeters buffer }\end{array}$ & 471 & 648 & 445 & 570 & 2134 \\
\hline $\begin{array}{c}\text { Geocoded Students } \\
\text { Number of students in 500 } \\
\text { meters buffer }\end{array}$ & 441 & 629 & 415 & 554 & 2039 \\
\hline $\begin{array}{c}\text { Number of students in 1500 } \\
\text { meters }\end{array}$ & 462 & 378 & 385 & 387 & 1613 \\
\hline
\end{tabular}

and $25 \%$ for the $7^{\text {st }}$ until $9^{\text {th }}$ grade). Nevertheless, adult company is higher (50\%) on the way to school of children than on their return home (28\%). EBCCB registers the highest number of journeys made on adult company (46\%) and EBAP the lowest number (26\%). In the total of the schools, is estimated that daily journeys to/from school involve not only 2134 students but also 768 adults, average of 1,4 persons.

Journeys to/from school carpool by the students were registered in the all schools; $62 \%$ of the vehicles carry more than one student. The occupancy rate of the vehicles is 1,7 student/vehicle, with little noted differences. 


\section{$5.6 \mathrm{Co}_{2}$ emissions}

Based upon the number of journeys made by students using motorized transports and by the additional journeys of them parents to take and bring children were established $\mathrm{Co}_{2}$ emissions, per day, for each school and by each grade. In the total of four schools, is estimated that journeys to/from school register $\mathrm{Co}_{2}$ emissions of $784 \mathrm{~kg} /$ day, $32 \%(254 \mathrm{~kg})$ resulted from students journeys to/from school, and $68 \%$ (530 kg) from the additional journeys of them parents to take and bring back their children. The $5^{\text {th }}$ and $6^{\text {th }}$ grade is responsible for $46 \%$ of the total of the emissions, the $7^{\text {th }}$ until $9^{\text {th }}$ grade for $36 \%$ and the $1^{\text {st }}$ until $4^{\text {th }}$ grade for $37 \%$ of the total of the emissions of $\mathrm{Co}_{2}$ being the EBAP the school with lower volume of emissions (13\%).

Emissions/student/day ratio it's higher in the $5^{\text {th }}$ and $6^{\text {th }}$ grade (438 gr/student/day) and lower in the $7^{\text {th }}$ until $9^{\text {th }}$ grade $(295 \mathrm{gr} / \mathrm{student} /$ day $)$. EBCCB and EBJR both present a ratio above $400 \mathrm{gr} / \mathrm{student} /$ day (451 e $410 \mathrm{gr})$, meanwhile EBAP emissions are only 219 gr and EBFV 349 gr.

Schools that registered higher levels of emissions resulted from the additional journeys of parents to drive their children to school, than the journeys of their children to school, with the maxim value to EBJR (82\%) and the minim to EBAP $(57 \%)$.

\section{Discussion}

Considering the small size city and the schools' location in the urban structure has the problem of the overlap of the 1500 buffer that results in the same caption of students, since home to school distances are short. Thus, the urban structure may be residual influence in mobility patterns of journeys to/from school and mode choices of parents and students, when compared with other individual, social and economic factors related to environmental perceptions that are not considerable.

On the other hand, the number of case studies is low not allowing us to take considerable final conclusions about the influence of urban structure in mobility patterns in home to school journeys.

However, according to the obtained results, urban structure has an influence on mobility patterns in daily journeys to school to/from the schools, particularly so in EBCCB, which is located in urban periphery, particularly residential, low density, etc. This urban structure may explain the mobility pattern characterized by driving (59\%), longer time journeys (10 minutes/journey) and higher $\mathrm{Co}_{2}$ emissions levels (451 gr/student/day).

Peripheral urban schools, EBFV and EBCCB, have better performance on neighborhood function and school proximity. In the buffer of 500 meters not present higher attractiveness rates (38\% and 40\%) and lower distances home to school (263 and 229 meters).

The school EBFV, located in urban periphery of high density and especially residential with a lack of community services, green area and public area, is better integrated in the neighborhood. Walking represents $62 \%$ of trips to/from school, lower time per student (6 minutes) and additional times of parents 
journeys to take or pick up their children (2,9 minutes / student), lower $\mathrm{Co}_{2}$ emissions (349 gr/student/day) and higher walking rate of journeys in adults company (28\%).

Even presenting proximity of 300 meters, EBAP and EBJR located near the city center (higher density and diversity land use areas) present distinct results. EBAP presents the lower level of $\mathrm{Co}_{2}$ emissions (219 gr/student/day) and lower additional times of parents journeys to take and pick up their children $(1,8$ minutes/ student and 890 meters / student). On the other hand, EBJR present the higher value distance/student in 500 buffer (359 meters), the lower distance/ student (1046 meters), higher values in additional times journeys of parents to take and pick up their children (4,8 minutes/ student and 2423 meters/ student) and high $\mathrm{Co}_{2}$ emissions (410gr/student/day).

Central location of schools, higher density and diversity of land uses as well better infrastructures and community services result in different mobility patterns for the schools. EBJR presents a mobility pattern less sustainable than in urban peripheral schools. The centrality works as a "Pandora Box", considering that the perception of the environment by parents and students may conduct them to unpredictable behaviors. Personal safety, road safety, more intensive flow or local transportation policies may be the origin of the less sustainable travel behaviors. Thus, is necessary to introduce other explanatory factors in mobility patterns in home to school journeys.

The group age, individually, or associated to other factors, may perform an important role to distinguish the mobility patterns between the four schools in study. How it's referred in other cases study the environmental perception and capacity to pass the barriers are different according to students age [18].

\section{Future developments}

Considering the actual stage of the project it wasn't possible to take another approach. The number of study schools $(n=4)$ is not considerable for the use of modeling the relations between urban form and mobility patterns.

Furthermore, the research will approach 3 different topics. The first will be to improve the information about urban structure (connectivity of streets, streets topography, wide sidewalks, etc.). Secondly, will be enlarge the number of schools study cases, considering regression models to analyze the relations between urban structure and scholar mobility patterns. The third one will be to analyze desegregated data to each student and report logistic regression analyses towards the modeling of relations between urban structure and travel to school mode choices.

\section{Final notes}

Considering the average distance/student from home to school is 1464 meters, the relation between the urban structure and scholar mobility patterns are not clear for small sized cities. Similar sized schools with the same number and aged students may present distinct scholar mobility patterns. The distance between home and 
school appears as a contradictory effect in mobility patterns can't explain them. Other economic, social and psychological factors related with individual characteristics (age and environmental perception by parents and students) may influence mobility patterns in travel to school in a small sized cities.

\section{Acknowledgement}

The results of this paper become from a Research Project support by Fundação Calouste Gulbenkian.

\section{References}

[1] ABCittà, www.percorsicasascuola.it/home.html

[2] ADEME, www.ademe.fr/

[3] DFT, www.dft.gov.uk/pgr/sustainable/schooltravel/

[4] IWALK, www.iwalktoschool.org/

[5] SCHOOLWAY, www.schoolway.net

[6] TRAVELTOSCHOOL, www.traveltoschool.com/

[7] VÉLO QUÉBEC, www.velo.qc.ca/monecole/

[8] EC, www.ec.europa.eu/transport/urban/

[9] Alves, R. Sustainable mobility in medium sized cities, communication presented at Conference Sustainable Mobility Project, 19 September, 2008, Lisbon, PT, http://sniamb.apambiente.pt/mobilidade/

[10] Ewing R., Schroeer W., Greene W. School location and student travel analysis of factors affecting mode choice. Journal of the Transportation Research Board, 1895, pp.55-63, 2004.

[11] Handy, S. L., Boarnet, M. G., Ewing, R., \& Killingsworth, R. E. How the built environment affects physical activity: Views from urban planning. American Journal of Preventive Medicine, 23(2S), pp. 64-73, 2002.

[12] McDonald, N. C. Children's Mode Choice for the School Trip: The Role of Distance and School Location in Walking to School. Transportation, 35(1), pp. 23-35, 2008.

[13] McMillan T.E. The relative influence of urban form on a child's travel mode to school. Transportation Research Part A: Policy and Practice 41, pp.69-79, 2007.

[14] Panter J. R., Jones A. P. and Mf van Sluijs E. M. Environmental determinants of active travel in youth: A review and framework for future research. International Journal of Behavioral Nutrition and Physical Activity, pp.5-34, 2008.

[15] Schlossberg M., Greene J., Phillips P., Johnson B., Parker B. School trips: Effects of urban form and distance on travel mode. Journal of American Planning Association, 72, pp.337-346, 2006.

[16] Cervero, R. \& Kockelman, K. Travel Demands and the 3 Ds: Density, diversity and design. Transportation Research Part D, 2(3), pp. 199-219, 1997.

[17] ESTCB, www.est.ipcb.pt/mobilidadeescolar/ 
[18] Timperio A. B., Salmon J. R., Giles-corti B, Simmons D,B., Crawford D. Personal, family, social, and environmental correlates of active commuting to school. American Journal of Preventive Medicine, 30, pp.45-51, 2006.

[19] DFT, www.dft.gov.uk/about/strategy/

[20] MTNW, www.transport.govt.nz/ 